УДК 351

DOI: https://doi.org/10.26642/jen-2020-2(92)-69-73

\author{
В.В. Іванюта, к.держ.упр. \\ Державний університет «Житомирська політехніка»
}

\title{
Забезпечення економічної безпеки на регіональному рівні як напрям державного впливу
}

\begin{abstract}
В Україні розуміння економічної безпеки на законодавчому рівні не визначене як об'єкт державного впливу; засоби впливу, здебільшого, орієнтовані на схожі способи управління регіональною економічною системою. Показано необхідність пошуку і розроблення найбільш ефективних методів управління щуодо забезпечення економічної безпеки, зокрема на регіональному рівні. Доведено, щзо забезпечення економічної безпеки на регіональному рівні має трунтуватися на дослідженні специфіки і систематизації ризиків та загроз, характерних для конкретного регіону. Визначено, щчо головною метою державного управління щуодо гарантування економічної безпеки регіону $\epsilon$ попередження загроз $i$ підтримання загальної стійкості регіональної економічної системи. У результаті аналізу основних проблем щзодо забезпечення економічної безпеки країни було уточнено сутність економічної безпеки регіонів як однієї зі складових забезпечення начіональної безпеки на сучасному етапі суспільного розвитку.
\end{abstract}

Ключові слова: державне управління; економічна безпека; загрози; об'єкт державного впливу; ризики; регіон.

Актуальність теми. Сучасний розвиток національної економіки характеризується наявністю безлічі різноманітних загроз, які перешкоджають іï стабільному функціонуванню. За таких обставин важливого значення набуває гарантування національної безпеки України, зокрема економічної безпеки регіонів, які $\epsilon$ найважливішою іiі складовою. При цьому вирішення актуального завдання гарантування економічної безпеки на рівні регіону зумовлено ускладненням геополітичної ситуації і періодично виникаючими економічними кризами, що виводить питання забезпечення економічної безпеки територій на новий рівень наукових досліджень і практичних розробок.

Аналіз останніх досліджень і публікацій. Основи економічної безпеки держави, її нормативноправову базу, методологію та базові принципи державного управління закладено в наукових працях різних представників економічної думки: В.Гейця, З.Варналія, О.Барановського, Л.Абалкіна, В.Білоуса, С.Глазьєва, В.Сенчагова, Є.Олейнікова, О.Власюка, Я.Жаліла, В.Мунтіяна, Г.Ситника та інших. Однак на сьогодні питання економічної безпеки регіонів України залишаються актуальними.

Постановка завдання. Мета статті - розглянути теоретичні підходи дослідження сутності поняття «економічної безпеки регіону» i запропонувати науковий підхід до визначення специфіки та систематизації ризиків і загроз, характерних для різних типів регіонів.

Викладення основного матеріалу. Значення і гострота проблем, пов'язаних з безпекою як на переломних етапах розвитку суспільства, так і в сучасних умовах, постійно зростає. Безпека продовжує залишатися основною, базовою потребою для людини й бажаним станом особистості, суспільства та держави. Сьогодні не викликає сумніву, що економіка $є$ основоположною сферою діяльності суспільства, а сам зміст поняття «економічна безпека» не обмежується лише аспектами, які торкаються економічних процесів, що відбуваються в регіоні або в країні у цілому.

У вітчизняній і зарубіжній економічній теорії необраний загальний підхід до характеристики змісту поняття «економічна безпека». 3 точки зору більшості зарубіжних дослідників економічна безпека $\epsilon$ вагомою складовою національної безпеки країни і досить рідко розглядається як окрема категорія, яка показує характеристику окремих територій, господарюючих суб’єктів і особистості. Безпосередньо економічна безпека пов'язана зі стабільним економічним зростанням, незалежністю і збереженням суверенітету держави. У низці зарубіжних наукових досліджень немає очевидних розмежувань між економічною безпекою і економічними аспектами національної безпеки країни. До того ж у деяких Європейських країнах, наприклад в Угорщині, економічну безпеку як елемент національної безпеки не представлено. В межах зазначеної Стратегії розглядаються тільки аспекти фінансової безпеки, енергетичної, а також кібербезпеки, які, в свою чергу, є складовими економічної безпеки.

Пошуку найбільш точного змісту поняття «економічна безпека» 3 боку вітчизняних дослідників і політичних діячів приділяється особлива увага, тому що проблематика самого поняття знаходиться на перетині економічної, фінансової, соціальної, правової, екологічної, енергетичної, продовольчої та інших сфер. В умовах сучасної економічної і політичної ситуації досить вагомим кроком є закріплення визначення поняття «економічна безпека» на законодавчому рівні. Офіційно економічна безпека України гарантується відповідно до Конституції України. Також слід звернути увагу на Закон України «Про засади внутрішньої і зовнішньої політики» та «Про національну безпеку України», де визначено виклики 
і загрози національної безпеки, основною складовою якої є економічна безпека країни, вказані цілі, основні напрями та завдання державної політики у сфері гарантування економічної безпеки.

Також активно відбувається закріплення поняття «економічна безпека» 3 позиції економіко-правових, бюджетних, соціально-економічних і екологічних відносин. Якщо розглядати категорію «економічна безпека» $з$ точки зору стійкості розвитку (серед наукових дослідників економічної безпеки таку думку поділяють О.Г. Данільян, Б.Ф. Заблоцький, Г.Ф. Костенко, В.А. Ліпкан, Н.Р. Нижник, А. Сухоруков та ін.), то в межах визначеного аспекту необхідною умовою підтримки економічної безпеки $є$ збереження $\mathrm{i}$ поліпшення екологічної складової одночасно з проведеними перетвореннями в економіці, політиці та соціальній сфері. У такому випадку виникає також необхідність вивчення конкретного стану економіки, за якого забезпечується досить високий і стійкий економічний ріст, ефективне задоволення економічних потреб, контроль держави за рухом і використанням національних ресурсів, а також захист економічних інтересів країни на національному і міжнародному рівнях. Справедливо у своєму дослідженні зазначає Г.П. Ситник, що наявність економічної безпеки дозволяє оптимізувати витрати ресурсів, направити їх не на захист від негативних впливів (ризиків і загроз), а на відтворення матеріальних і нематеріальних благ [6].

Протягом майже трьох останніх десятиліть неодноразово робилися спроби вітчизняних дослідників дати найбільш точну i повну характеристику категорії «економічна безпека». Здебільшого все визначення, у кінцевому підсумку, кореспондують тільки із загальним визначенням поняття «безпека», в тому числі з їі базовими складовими, цілком опираючись на такі терміни, як «захищеність національних інтересів», «захищеність життєво важливих інтересів», «захист від зовнішніх і внутрішніх загроз», «поєднання економічних, політичних умов», «стійкість соціально-економічного розвитку», «стан економіки», «незалежність національної економіки» та ін.

Незважаючи на те, що існують різні теоретичні підходи до визначення поняття «економічна безпека», вважаємо за необхідне конкретизувати й адаптувати його зміст для поняття «економічна безпека території» $з$ метою подальшого аналізу його складових.

У вітчизняних дослідженнях, присвячених проблематиці економічної безпеки регіонів, використовуються два змістовно тотожних терміни: «економічна безпека регіону» і «регіональна економічна безпека».

Теорія економічної безпеки регіону взаємопов'язана з усіма напрямами теорії регіональної економіки, тому що досліджує зміни стану соціально-економічної системи регіону. Для досягнення безпечного стану регіону з позиції соціально-економічного розвитку, що являє собою основний напрям теорії регіональної економіки, найчастіше розглядається у загальному вигляді підвищення якості та рівня життя населення регіону. Однак немає жодної теорії, яка стверджує, що при досягненні високого рівня соціально-економічного розвитку автоматично відбудеться підвищення рівня економічної безпеки. Тож можна зробити висновок, що методологічна основа теорії економічної безпеки регіону щонайменше вибудовується на трьох основах: теорія економічної безпеки (понятійно-категоріальний апарат, ідентифікація загроз і способи їх оцінки), теорія регіональної економіки (понятійно-категоріальний апарат, способи розміщення продуктивних сил, застосування певних інструментів та механізмів, спрямованих на соціально-економічний розвиток регіону), ордоліберальна теорія (способи побудови соціально-орієнтованої економіки).

Незважаючи на схожість підходів у визначеннях поняття, все ж є й суттєві відмінності. У багатьох визначеннях розкривається зміст економічної безпеки регіону за допомогою засобів виокремлення загроз, а також можливих інструментів, спрямованих на мінімізацію та усунення цих загроз, в деяких позначено суб'єкти, тобто виокремлено основне джерело, яке безпосередньо впливає на об'єкт економічної безпеки регіону. Таким чином, охоплено не лише суб'єктно-об'єктні та предметні відносини у визначеннях, а й спроби максимально відобразити складові економічної безпеки регіону. Це вчергове доводить, що в науці склалося розуміння щодо економічної безпеки регіону як практичної характеристики стану його соціально-економічної системи.

Узагальнюючи зазначене вище припускаємо, що найбільш точним об'єктом економічної безпеки регіону доцільно вважати не тільки економіку регіону, а й соціально-економічну систему (особливо ії ступінь розвитку і готовність до протистояння внутрішнім і зовнішнім загрозам).

В такому випадку, з огляду на те, що на об'єкт впливає суб'єкт, логічно припустити, що суб'єктом економічної безпеки регіону може бути не лише управління його соціально-економічною системою, яке, насамперед, відбувається завдяки нормативно-правовим актам, встановленню програм розвитку регіону в усіх сферах, реалізації захисту і практики попередження виникнення загроз, а й дестабілізація процесів, що можуть негативно вплинути на безпеку соціально-економічної системи регіону.

У більшості визначень фігурують і фактори, які впливають на стан економічної безпеки регіону: зміна показників якості життя населення, посилення негативних впливів, зміна стану соціальноекономічних відносин регіональної економічної системи тощо. Крім факторів, вченими виокремлено два блоки загроз: внутрішні та зовнішні. Особливий інтерес для подальшого дослідження, 3 точки зору вирізнення більш обмеженого переліку загроз, має визначення О.С. Власюк, згідно з яким економічна 
безпека розуміється як характеристика основних показників соціально-економічних параметрів розвитку, за якої забезпечується виявлення і попередження виникнення загроз розвитку ключових сфер економіки, що визначають хід відтворювального процесу в регіоні [1]. Безумовно, конкретизація загроз економічній безпеці регіону в усіх з наведених визначень буде базуватися на індивідуальному підході автора, тобто через які сфери або особливості він розуміє економічну безпеку регіону.

Під час проведеного аналізу все ж необхідно підкреслити той факт, що економічна безпека $\epsilon, \mathrm{y}$ першу чергу, якісною характеристикою соціально-економічної системи і всі теоретичні підходи зосереджені на охопленні чинників, здатних як позитивно, так і негативно впливати на стан соціальноекономічної системи. Підтвердженням цього є визначення А.Б. Качинського: «стан, в якому відсутні, зведені до мінімуму або усунені внутрішні і зовнішні загрози для збереження соціально-економічного i фінансового потенціалу регіону не нижче рівня, достатнього для підвищення добробуту його населення» [3]. Також вчений зазначає, що якщо економіка не розвивається, то різко скорочуються можливості ії виживання, а також опір і пристосованість до внутрішніх і зовнішніх загроз. Тим самим підкреслюючи важливість розвитку як компоненти економічної безпеки.

Економічна безпека на будь-якому з їі рівнів, зокрема на регіональному, має розглядатися як система відносин суспільства й держави, а отже, основним підходом до вивчення проблем економічної безпеки має бути системний підхід. Підтвердження цього - аналіз вибірки визначень економічної безпеки, який продемонстрував і підтвердив, що економічна безпека є міждисциплінарним дослідженням, базується на перетині таких наук як економіка, право, юриспруденція, соціологія тощо.

Підсумовуючи проведений аналіз можна зазначити, що економічно безпечний стан регіону залежить від ступеня задоволеності потреб населення, при цьому для кожного регіону встановлюються власні кордони критичного рівня можливих загроз, тому що до уваги береться, насамперед, досягнутий рівень розвитку регіону та його особливості. Тенденція, яка характерна для всіх регіонів України, полягає в тому, що декларування соціально-економічного розвитку фактично зводиться до забезпечення мінімально необхідних соціальних стандартів життєдіяльності населення. Оціночні показники рівня та якості життя населення не рідко порівнюються 3 мінімально-встановленими (як приклад, споживчий кошик). Тому пріоритетним напрямом розвитку теорії економічної безпеки регіону може стати уточнення параметрів мінімальних соціальних стандартів у регіоні, допустимих для безпечного існування його населення. Таким чином, основним завданням підтримки на високому рівні економічної безпеки регіону є не тільки досягнення високих соціально-економічних і виробничих показників, а й розробка реально діючих інструментів, спрямованих на запобігання загрозам, з огляду на те, що ступінь загроз регіонів істотно різниться. Варто також зауважити, що проблема економічної безпеки відчутна для місцевої влади. Це підтверджується ії спробами самостійно вибудовувати практичні рішення у сфері управління економічною безпекою.

На основі розглянутих теоретичних підходів до визначення поняття «економічна безпека регіону» запропонуємо власне розуміння економічної безпеки як характеристики досягнутого стану його соціально-економічної системи, що полягає у здатності протистояти можливим внутрішнім і зовнішнім загрозам завдяки доступним інструментам управління та засобам захисту, які максимально охоплюють усі сфери життєдіяльності суспільства.

Основу запропонованого визначення становить захист соціально-економічної системи регіону й, відповідно, дослідження категорії «економічна безпека регіону», яка базуватиметься на детальному аналізі загроз, їх кількісної та якісної оцінки, а також розгляді можливих варіантів регулювання та інструментів запобігання загрозам.

Головною метою економічної безпеки регіону є захист регіональних економічних інтересів. При цьому економічну безпеку необхідно розглядати в системі сталого розвитку регіону. Відповідно до Стратегії національної безпеки України [5] процес економічних і соціальних змін не порушує та не завдає шкоди екологічній складовій. Щодо соціально-економічних систем сталий розвиток - це здатність підтримувати такий стан, коли всі природні, виробничі, матеріальні, трудові й фінансові ресурси використовуються найбільш ефективно для розвитку соціально-економічної стабільності (в тому числі економічної безпеки) протягом довгострокового періоду часу, при цьому забезпечуючи і підтримуючи на досить високому рівні попередження й запобігання різного роду загроз. Таким чином, під стійким розвитком регіону будемо розуміти процес змін, спрямованих на довгостроковий збалансований розвиток усіх сфер, 3 метою забезпечення відтворюваності ресурсів, необхідних для якісного життя нинішніх і майбутніх поколінь. У контексті стійкості розвитку економічна безпека регіону передбачає: збереження ресурсного потенціалу; здатність регіону самостійно реалізовувати й захищати регіональні економічні інтереси; як джерело регіонального економічного зростання, слід вирізнити активізацію трудової діяльності (переважно для ключових галузей регіональної політики); збалансоване формування соціально-економічного розвитку регіону та його фінансово-господарську самостійність. Гарантування економічної безпеки регіону залежить від ефективності економіки. Тому регіональне управління має, насамперед, забезпечити розширення економічних можливостей, а також якісно поліпшити стан складових економічної безпеки регіону. 
Серед складових економічної безпеки регіону можна виокремити: фінансову безпеку, покликану забезпечити захист фінансових відносин всіх елементів фінансової системи регіону; інвестиційну безпеку як підсистему фінансової безпеки; промислову безпеку, що містить низку елементів, які фактично охоплюють галузеву структуру регіональної економіки (техніко-виробниче забезпечення регіону, енергетичну та транспортну безпеку); продовольчу безпеку; інформаційну безпеку; екологічну безпеку.

Беручи до уваги важливість кожної складової системи економічної безпеки, вважаємо справедливим таке судження: результативністю, досягненням безпечного стану кожної складової, у кінцевому підсумку, буде соціальна безпека, яка теж входить у структуру економічної. Будь-який прояв загроз у технологічній, фінансовій та в інших сферах, перш за все, негативно відображається на соціальній. Таким чином, соціальна безпека як невід'ємний елемент економічної характеризує такий стан суспільства, органів державного управління, сфери виробництва, культури та інших сфер соціальної та економічної діяльності, який гарантує мінімальний ризик для життя та здоров'я людей і визначає якість життя населення [4]. Тому дослідження соціального аспекту в структурі економічної безпеки необхідне для забезпечення дієвої системи управління. Завдання реалізації економічної безпеки регіону знаходиться на перетині об'єктів безлічі сфер і у кінцевому підсумку результатом досягнення економічно безпечного стану буде, насамперед, захист соціально-економічної системи регіону. Отже, явище економічної безпеки є соціальним. 3 огляду на те, що сама категорія «соціальна безпека» грунтується на стані соціальної системи, рівні їі розвитку і здатності до стійкого відтворення основних системних елементів, що забезпечують їі функціонування, то економічна безпека безпосередньо взаємопов'язана із соціальною безпекою, тобто обидві категорії доповнюють одна одну: не може бути високого рівня захищеності соціальної сфери при слабкій економіці.

Таким чином, до можливих загроз економічній безпеці регіону в соціальній сфері можна зарахувати: зниження рівня та якості надання соціальних послуг (освіти, охорони здоров'я), зниження рівня та якості життя в регіоні, збільшення розшарування суспільства за рівнем доходів, підвищення рівня злочинності, зниження рівня народжуваності, підвищення смертності, погіршення ситуації у соціально-значущих сферах, зростання безробіття, корупцію, зниження реальних доходів тощо.

Не менш значущою складовою в системі економічної безпеки регіону є підтримання на належному рівні фінансової безпеки. Традиційно в структурі цієї складової виокремлюють податкову безпеку, сферу фінансово-грошового обігу, інвестиційну складову, а також на рівні держави - бюджетну безпеку, безпеку кредитно-банківської системи, валютну безпеку тощо. Відсутність фінансових коштів призводить до недофінансування найнагальніших потреб у різних сферах економіки, чим викликає у цих сферах загрози. До того ж далеко не всі регіони України мають достатньо коштів, що переважно негативно впливає на стан економічної безпеки регіону.

Інвестиційна безпека може бути розглянута як окрема складова економічної безпеки, тому що, 3 одного боку, утворює інвестиційний потенціал та інвестиційну привабливість регіону, а 3 другого боку, характеризує ступінь впливу ризиків і загроз на соціально-економічну систему регіону.

Продовольча безпека займає одну з ключових позицій у системі економічної безпеки з огляду на те, що є одним 3 найважливіших інструментів забезпечення стійкості соціально-економічної системи регіону. Ступінь безпеки продовольчої сфери регіону може бути виміряна забезпеченістю населення якісним продовольством. Для більшості регіонів України характерна ситуація низької рентабельності функціонування продовольчих галузей економіки, що зумовлено недостатньо високими темпами технічної та структурно-технологічної модернізації агропромислового виробництва.

Промислова безпека кожного регіону багато в чому залежить від ступеня розвиненості галузей національного господарства, що утворюють конкурентоспроможність регіону. А також переважно покладається на існуючі доктрини у сфері енергетичної безпеки, хоча в загальній структурі економічної безпеки регіону оцінка промислової цілком базується на характеристиці ВРП.

Не можна недооцінити роль інформаційної безпеки як складової економічної безпеки регіону. Саме інформаційна безпека здатна забезпечити захист різного роду інформаційних ресурсів, що використовуються у процесі взаємодії суб’єктів економіки.

Визначивши, що економічну безпеку доцільно розглядати в системі сталого розвитку регіону, то застосування інструментів, що гарантують безпеку по кожній складовій, не має завдавати шкоди суміжній складовій економічної безпеки - екологічній безпеці регіону.

3 позиції управління економічною безпекою регіону соціально-економічна система є стійкою тоді, коли іiі складові успішно функціонують, при цьому виконуючи свої призначення. Через принципові відмінності між регіонами для оцінки їх економічної безпеки значущим є виявлення чинників, аналіз і моніторинг яких дасть змогу більш детально розглянути проведену регіональну політику в сфері економічної безпеки, виокремити пріоритетні напрями у боротьбі із загрозами, а також оцінити зміни, що відбуваються в соціально-економічній системі регіонів у цілому. До того ж дослідження взаємозв'язків між чинниками, здатними вплинути на стан економічної безпеки регіонів як прямо, так і опосередковано, зможе сприяти виявленню і запобіганню загроз на ранніх стадіях їх виникнення. 
Представивши складові економічної безпеки регіону в структурі системи сталого розвитку можна вирізнити ключові фактори стійкості розвитку регіону. До економічних чинників логічно зарахувати високий рівень економічного, інвестиційного та виробничого потенціалу, ефективне ведення зовнішньоекономічної діяльності, розвиненість науково-технічного потенціалу; до соціальних - якісну характеристику рівня життя населення, стан демографічного потенціалу регіону, розвиненість соціальної сфери та інфраструктури; до екологічних - раціональне використання природних ресурсів, стан природного середовища, екологічну ситуацію в регіоні в цілому.

Висновки. Обгрунтовано зміст авторського трактування категорії «економічна безпека регіону» на основі систематизації ризиків і загроз, характерних для різних типів регіонів. Зазначено, що під економічною безпекою регіону розуміється характеристика досягнутого стану його соціальноекономічної системи, яка полягає у здатності протистояти можливим внутрішнім і зовнішнім загрозам завдяки доступним інструментам управління та засобам захисту, які максимально охоплюють усі сфери життєдіяльності суспільства.

Відмінною особливістю запропонованого визначення $є$ виокремлення ризиків і загроз, характерних для різних типів регіонів, а тому й засоби державного управління економічною безпекою для кожного регіону мають бути індивідуальними.

\section{Список використаної літератури:}

1. Власюк O.C. Теорія і практика економічної безпеки в системі науки про економіку / О.С. Власюк. - К. : Нац. ін-т проблем міжнародної безпеки при Раді нац. безпеки і оборони України, 2008. - 48 с.

2. Економічна безпека : навч. посіб. / 3.С. Варналій та ін. ; за ред. д-ра екон. наук, проф. 3.С. Варналія. - К. : Знання, 2009. - 647 с.

3. Качинський А.Б. Індикатори національної безпеки: визначення та застосування їх граничних значень : монографія / А.Б. Качинський, Г.П. Ситник. - К. : НІСД, 2013. - 104 с.

4. Пастернак-Таранушенко Г.А. Економічна безпека держави / Г.А. Пастернак-Таранушенко. - К. : Ін-т держ. упр. і самовряд. при КМУ, 1994. - 112 с.

5. Про стратегію національної безпеки України : Указ Президента України від 22 черв. 2012 р. № 389/2012 [Електронний ресурс]. - Режим доступу : http://zakon4.rada.gov.ua/laws/ show/105/2007.

6. Ситник Г.П. Державне управління у сфері національної безпеки (концептуальні та організаційно-правові засади) : підручник / Г.П. Ситник. - К. : НАДУ, 2012. - 544 с.

7. Ткаченко В.Г. Некоторые положения сущности и содержания экономической безопасности государства / В.Г. Ткаченко // Экономист. - 2008. - № 9. - С. 9-11.

8. Экономическая безопасность Украины в условиях рыночных трансформационных процессов : монография / под общей ред. проф. В.Г. Ткаченко, проф. В.И. Богачева. - Ровеньки, 2007. - 330 с.

\section{References:}

1. Vlasiuk, O.S. (2008), Teoriia i praktyka ekonomichnoi bezpeky v systemi nauky pro ekonomiku, Nats. in-t problem mizhnarodnoi bezpeky pry Radi nats. bezpeky i oborony Ukrainy, Kyiv, Ukraine, 48 p.

2. Varnalij, Z.S. et al. (2009), Ekonomichna bezpeka, in Varnalij, Z.S. (ed.), Znannia, Kyiv, Ukraine, 647 p.

3. Kachyns'kyj, A.B. and Sytnyk, H.P. (2013), Indykatory natsional'noi bezpeky: vyznachennia ta zastosuvannia ikh hranychnykh znachen', NISD, Kyiv, Ukraine, 104 p.

4. Pasternak-Taranushenko, H.A. (1994), Ekonomichna bezpeka derzhavy, In-t derzh. upr. i samovriad. pry KMU, Kyiv, Ukraine, 112 p.

5. VRU (2012), «On the National Security Strategy of Ukraine», Ukaz Prezydenta Ukrainy vid 22 cherv. 2012 r. No. 389/2012, [Online], available at: http://zakon4.rada.gov.ua/laws/ show/105/2007

6. Sytnyk, H.P. (2012), Derzhavne upravlinnia u sferi natsional'noi bezpeky (kontseptual'ni ta orhanizatsijno-pravovi zasady), pidruchnyk, NADU, Kyiv, Ukraine, $544 \mathrm{p}$.

7. Tkachenko, V.G. (2008), «Some provisions of the essence and content of the economic security of the state», Ekonomist, No. 9, pp. 9-11.

8. Ekonomicheskaja bezopasnost' Ukrainy v uslovijah rynochnyh trans formacionnyh processov (2007), monografyja, in prof. Tkachenko, V.G. and prof. Bogacheva, V.Y. (ed.), Rovenki, Ukraine, 330 p.

Іванюта Вікторія Вікторівна - кандидат наук з державного управління Державного університету «Житомирська політехніка».

Наукові інтереси:

- публічне управління та адміністрування.

http://orcid.org/0000-0002-4037-5590. 